\title{
NECESSITY AND WAYS TO INCREASE ADAPTIVE POTENTIAL OF DRIED LAND IN CHANGEABLE CLIMATIC CONDITIONS
}

\author{
Anatoly Rokochynskiy ${ }^{1}$, Yury Mazhayskiy ${ }^{2}$, Pavlo Volk ${ }^{1}$, Jerzy Yeznah ${ }^{3}$, Aliaksandr Volchak ${ }^{4}$, \\ Aleh Meshyk ${ }^{4}$, Olga Chernikova ${ }^{5}$, Nataliia Prykhodko ${ }^{1}$ \\ ${ }^{1}$ National University of Water and Environmental Engineering, Russia; ${ }^{2}$ All-Russian Research \\ Institute of Hydrotechnics and Melioration named after A.N. Kostyakova, Russia; ${ }^{3}$ Warsaw University \\ of Life Sciences, Poland; ${ }^{4}$ Brest State Technical University, Belarus; ${ }^{5}$ Academy of Law Management \\ of the Federal Penal Service of Russia, Russia \\ a.m.rokochinskiy@nuwm.edu.ua, director@mntc.pro,p.p.volk@nuwm.edu.ua, \\ jerzy_jeznach@sggw.edu.pl,volchak@tut.by, omeshyk@gmail.com, chernikova_olga@inbox.ru, \\ n.v.prykhodko@nuwm.edu.ua
}

\begin{abstract}
The ongoing climate change threatens a significant decrease in productivity in crop and livestock production, as well as degradation of ecosystems, which poses risks to the food security of the population and the well-being of future generations. The solution to this problem requires the development and implementation of adaptation strategies that can increase the productivity, efficiency and profitability of agricultural production. In accordance with the programmatic international and national documents on this issue (the UN Framework Convention on Climate Change, the Kyoto Protocol and the Paris Agreement, documents in the field of climate diplomacy in Ukraine and the EU as a whole, etc.), states, including Ukraine, have undertaken commitments to allocate funds for adaptation to climate change and preparation for their implementation. In agricultural production, reclamation traditionally plays a leading role in ensuring its sustainable development in adverse climatic conditions. Taking into account the expected climate changes, an extremely important role in adaptation of agriculture to it and, first of all, crop production, is played by water, hydrotechnical, agrotechnical and other types of reclamation. Therefore, there is a need to develop and implement adaptive measures for agricultural production on lands with a regulated water regime, including drained ones, in changeable climatic conditions to effectively counter modern challenges - energy, food and water crises, which are intensifying due to ongoing climate changes. Based on the analysis and generalization of the data of domestic and foreign scientists and specialists, as well as the results of our respective research, an assessment of the current state of changes in the weather and climatic conditions in the Polesie zone and their impact on agricultural production, fertility and moisture supply of soil, the conditions of functioning of water management and reclamation facilities, the natural and reclamation state of the drained lands was given. The general recommendations for the development of adaptive organizational and economic, operational and agrotechnical, construction and project activities that have their own clear goals and are closely interrelated were considered. On this basis, a complex of adaptive agromeliorative, agrotechnical and hydrotechnical measures has been developed and proposed, aimed at a gradual transition to the cultivation of new varieties and types of agricultural crops, effective regulation of the water regime of drained lands and the functioning of drainage systems in variable climatic conditions. This will allow minimizing the negative impact of climate change on soil processes and regimes, growing conditions and productivity of agricultural crops on drained lands using resource-saving technologies, taking into account modern economic and environmental requirements.
\end{abstract}

Keywords: adaptive potential, drained land, variable climatic conditions.

\section{Introduction}

Both at the global and regional levels, climate change has become an indisputable fact, the presence of which has posed the problem of solving a number of important and complex tasks related to the development and implementation of a strategy for its practical existence and adaptation to new climatic conditions. At the same time, the ongoing climate changes threaten a significant decrease in productivity in crop and livestock production, as well as degradation of ecosystems, which causes significant risks to food security of the population and the well-being of future generations. The solution to this problem requires the development and implementation of adaptation strategies that can increase the productivity, efficiency and profitability of agricultural production on the territory of the European Polesie of four neighboring states (Belarus, Ukraine, Poland, Russia) [1-5].

In agricultural production, reclamation traditionally plays a leading role in ensuring its sustainable development in adverse climatic conditions. Taking into account the expected climate changes, an extremely important role in adaptation of agriculture to it and, first of all, crop production, is played by water, hydrotechnical, agrotechnical and other types of reclamation. Therefore, there is a need to develop and implement adaptive measures for agricultural production on lands with a regulated water regime, 
including drained ones, in changeable climatic conditions to effectively counter modern challenges energy, food and water crises, which are intensifying due to ongoing climate change $[6 ; 7]$.

\section{Materials and methods}

The analysis and generalization of the content of the program international and national documents regarding the need and general recommendations for the development of adaptive measures related to climate change, the results of research and a general assessment of domestic and foreign scientists and specialists, as well as the results and our respective research were carried out. An assessment of the current state of changes in the weather and climatic conditions, on the example of the Western Polesie zone of Ukraine, and their impact on the efficiency of agricultural production, fertility and moisture supply of soil, the conditions for the functioning of water management and reclamation facilities, the natural reclamation state of drained lands was given and general recommendations for the development of adaptive organizational and economic, operational and agrotechnical, construction and project activities that have their own clear goals and are closely interrelated were considered [6-8].

The methods of our research on climate change, its impact on different aspects of agricultural production on drained lands in order to develop appropriate adaptation measures are based on the use of an appropriate set of predictive and simulation models, which includes a terrain climate model, a model of water regime and technologies for water regulation of drained lands, the model of development and formation of the yield of cultivated crops and are implemented on the basis of a long-term forecast $[6 ; 9]$. The basic methods of the general theory of experiment were also used: analytical, experimental and statistical; mathematical modeling and machine experiment using modern information and computer technologies. The processing of the results of field research and simulation data was carried out using the methods of mathematical statistics, probability theory and correlation analysis.

\section{Results and discussion}

The fact of global climatic changes is recognized by the world community and is beyond doubt today $[10 ; 11]$. The problem of global warming arose at the end of the last century, and subsequently, due to its increasingly tangible negative impact, the relevance only increases [8; 9]. In 1988, the Intergovernmental Panel on Climate Change (IPCC) was established by the World Meteorological Organization and the United Nations Environment Program to assess the state of global warming and the associated risks [12-14]. Recognition of global climate change on the planet and their negative consequences for humanity was declared by the international community in 1992 by the adoption of the UN Framework Convention on Climate Change (UN FCCC) - the agreement was signed by more than 180 countries of the world [15; 16]. In Paris (France) on June 17, 1994, the UN Convention to Combat Desertification and Drought was adopted and opened for signature. In 1997, the UN Framework Convention on Climate Change was supplemented by the Kyoto Protocol [15].

Later, in connection with an increase in the rate of warming, in 2015 the Paris Agreement was adopted, the main goal of which is to keep the growth of global temperature in the 21 st century within $2{ }^{\circ} \mathrm{C}$ and the possibility of its reduction to $1.5^{\circ} \mathrm{C}[16 ; 17]$.

The solution to this problem requires the development and implementation of adaptation strategies that can increase the productivity, efficiency and profitability of agricultural production [4-6; 10].

According to the United Nations Framework Convention on Climate Change, adaptation means adjustments in natural, social or economic systems in response to actual or expected climate changes, as well as their consequences [15].

To clarify and expand the applicability of the concept of adaptation to climate change conditions, the following categories were also considered and clearly defined: adaptation potential; tendency to influence; sustainability; risk; sensitivity; vulnerability [17].

In accordance with the programmatic international documents devoted to this issue in the field of climate diplomacy in Ukraine and the EU as a whole, as well as a strategy based on real research according to the IPPC criteria on climate change in Ukraine until 2100 and pursuant to the Decree of the President of Ukraine "On the decision of the Council of the National security and defense of Ukraine" of September 14, 2020 and "On the National Security Strategy of Ukraine", etc. Ukraine, like 
other participating states, has undertaken to allocate funds for adaptation to climate change and preparation for their implementation [18].

Along with the energy, food and water crises, climate change is one of the main challenges of our time. Thus, the unpredictability of weather conditions, which endangers food production, provokes a rise in sea level, increases the risk of natural disasters and anomalous phenomena that manifest themselves in various forms (drought, waterlogging, flooding of territories and etc.) and are the consequences of climate change, have a global character and unprecedented scale. However, most of the impacts of climate change are expected to persist for several centuries. Therefore, if decisive action is not taken today, then the subsequent adaptation to climate change will require a lot of effort and expense.

To assess the possible consequences of climate change as a whole for the current period, 12 scenarios of the impact on its changes were developed: for each of the three global climate models (GCM) (GISS, GFDL, UKMO), four scenarios were identified (GCM without a direct influence of $\mathrm{CO}_{2}$ on yield, with direct impact of $\mathrm{CO}_{2}$ on yield, with direct effects of $\mathrm{CO}_{2}$ and adaptation of the 1st level, with direct effects of $\mathrm{CO}_{2}$ and adaptation of the 2 nd level). The IBSNAT model was used to assess how climate change and rising carbon dioxide levels could change the world's crop production at 112 sites in 18 countries.

Ukraine is also among the regions of the planet, where the ongoing climate changes are tangible. According to the generalized data of the research results of specialists and scientists of Ukrhydromet, the Institute of Water Problems and Reclamation of the National Academy of Agrarian Sciences of Ukraine (NAAS), as well as the Odessa State Ecological University [10] over the past thirty years, the average annual air temperature has increased by $1.2^{\circ} \mathrm{C}$ in the country as a whole.

According to the results of assessing the regional warming rates, it was found that in the south and north-east of the country in 1991-2019 the average annual air temperature turned out to be by $1.0-1.1^{\circ} \mathrm{C}$ higher than for the standard period (1961-1990), in the west - by $1.2-1.3^{\circ} \mathrm{C}$, and in the north and in the central regions - by $1.4-1.5^{\circ} \mathrm{C}$. That is, the growth rate of air temperature for $1975-2019$ ranges from 0.61 to $0.82{ }^{\circ} \mathrm{C}$ per 10 years, while in the neighboring post-Soviet countries (Russia, Moldova, Belarus) $-0.47-0.59^{\circ} \mathrm{C}$ per 10 years [1], and in the northern hemisphere and Europe -0.34 and $0.47{ }^{\circ} \mathrm{C}$ per 10 years, respectively. These data indicate that the rate of air temperature rise in Ukraine is much higher than the European and global scales.

Usually, an increase in air temperature increases the moisture holding capacity of the atmosphere [1]. With an increase in air temperature by $1{ }^{\circ} \mathrm{C}$, the water-holding capacity of air increases by about $7 \%$ [1;2], which leads to an increase in potential evaporation [1].

According to the calculations of scientists from the Institute of Water Problems and Land Reclamation of the NAAS [1], an increase in the average monthly air temperature by $1{ }^{\circ} \mathrm{C}$ increases the potential average monthly total evaporation (excluding other factors) by $9 \%$. In this regard, there are six main typical zones in Ukraine: excessive moisture supply - occupies $4.5 \%$ of the territory; humid $30.0 \%$; insufficient moisture supply $-16.0 \%$; arid $-20.0 \%$; dry $-22.0 \%$; very dry $-7.5 \%$.

In the period from 1991 to 2015, compared to 1961-1990, territories with a significant deficit of natural moisture supply (dry and very dry zones) increased by $7 \%$ and cover a total of more than $29.5 \%$ of the area of Ukraine or 11.6 million hectares (37\%) of the country's arable land. At the same time, the territory of the country with excessive and sufficient atmospheric moisture, on the contrary, decreased by $10 \%$ and occupies only $22.5 \%$, including 7.6 million hectares of arable land.

According to the forecast until 2050, according to the scenario based on the A1B model [19], the general trend of an increase in the temperature regime by $1.24-1.48^{\circ} \mathrm{C}$ is expected, and with an increase in precipitation in general by $8 \%$ the climatic water balance of the territory of Ukraine may decrease by $45-115 \mathrm{~mm}$, and its deficit in the steppe zone will be $560 \mathrm{~mm}$ or more. Taking this into account, the territory of the country with an insufficient level of moisture will increase to $56 \%$, and only $28 \%$ of the territory will meet humid and excessively humid conditions.

In the long term, by the end of 2100, a part of the country's territory with an insufficient level of moisture can reach $71 \%$ against $50 \%$ in 1991-2015 with a simultaneous decrease in the area of arable land with sufficient moisture to 5.5-1.8 million hectares. 
In general, on the territory of Ukraine already in the twentieth century there was a general trend towards an increase in air temperature and an increase in the amount of atmospheric precipitation: so the annual temperature increased by $0.3-0.7^{\circ} \mathrm{C}$, and precipitation - by $50-100 \mathrm{~mm}$, the frequency of significant anomalies of both indicators also increased significantly (in 1.5 times). Their intraseasonal variability also increased. In all scenarios, the amount of precipitation will also increase. In some seasons, this increase may exceed the existing level by $20 \%[1 ; 19]$.

In the warm season, as a result of a sharp increase in the air temperature, most of the precipitation will be spent on evaporation. The main feature of the warming period is the constant unevenness of precipitation in the middle of the year and in certain years. At the same time, the greatest influence, due to global warming, is experienced by the Ukrainian Polesie zone during the winter and spring seasons.

On reclaimed agricultural lands with a close occurrence of the groundwater level, weather and climatic conditions are directly involved in the formation of the water regime of soil and groundwater, determining the direction of the soil processes both in the natural state and in certain technological periods of growing crops. In this regard, the forecast assessment of weather and climatic conditions is an essential condition for the implementation of the assessment of the overall efficiency of use and the ecological and reclamation state of drained lands.

To assess retrospective, modern and expected climate changes in the Western Polesie zone of Ukraine and its impact on the efficiency of agricultural production, soil fertility and moisture supply, the conditions for the functioning of water management and reclamation facilities, as well as with the aim of developing appropriate adaptation measures, we have planned and implemented a large-scale machine experiment using modern information and computer technologies. The research is based on the use of an appropriate complex of forecasting and simulation models and will include a model of the local climate, a model of the water regime and technologies for water regulation of drained lands, a model of the development and formation of the yield of cultivated crops, which are implemented on the basis of a long-term forecast [3].

With regard to our assessment of climate change, then, according to [7], the forecast was carried out:

- according to basic meteorological characteristics: air temperature, precipitation, relative humidity and air humidity deficit;

- for five groups of vegetation periods of estimated years in terms of total heat and moisture supply: very humid $-10 \%$; humid $-30 \%$; medium $-50 \%$; dry $-70 \%$; very dry $-90 \%$;

- for the following levels and corresponding periods of assessment: retrospective - 1945-1990; recent-1991-2015; forecast - for the climate model UKMO - the model of the United Kingdom Met Office, provides for an increase in the average annual air temperature by $6{ }^{\circ} \mathrm{C}$ when the $\mathrm{CO}_{2}$ content in the atmosphere doubles. In forecasting regime calculations, this model takes into account more critical scenarios of changes in weather and climatic conditions and is in better agreement with the models that we used for predictive assessment of the normalized distribution of the main meteorological characteristics in the long-term and intra-growing section.

The generalized results of the established average annual norms of vegetation values of the indicators of the main meteorological factors, as well as the possible nature of their change according to the considered levels and assessment periods, and the last real years (2015-2020) for the conditions of Western Polesie of Ukraine, are shown in Fig. 1.

The obtained results convincingly indicate that the predicted values of almost all the main meteorological indicators on the example of the Western Polesie zone of Ukraine, except the air temperature, are already within the limits of their current fluctuations and even exceed them in individual positions, which indicates a stable trend of changing climatic conditions in this region.

At the same time, for volatility, as the initial component of total evaporation, the nature of the change in this indicator for modern conditions relative to retrospective ones seems to be insignificant (an increase by $5.44 \%$ ), and for forecast conditions according to the UKMO model it is very significant $-27.2 \%$.

A detailed analysis by FAO [1] shows that climate change affects the agricultural sectors in many different ways, which vary from region to region. Some regions are expected to face prolonged droughts 
and water scarcity. The widespread melting of glaciers and snow cover in large mountain ranges, especially in Asia, will affect the volume and timing of water flows, ultimately reducing the availability of water for irrigation downstream. The increase in temperatures will lead to changes in the geography and frequency of disease outbreaks and pest outbreaks. In low-latitude regions, even a slight warming will lead to lower yields.

Precipitation amount, $\mathrm{mm}$

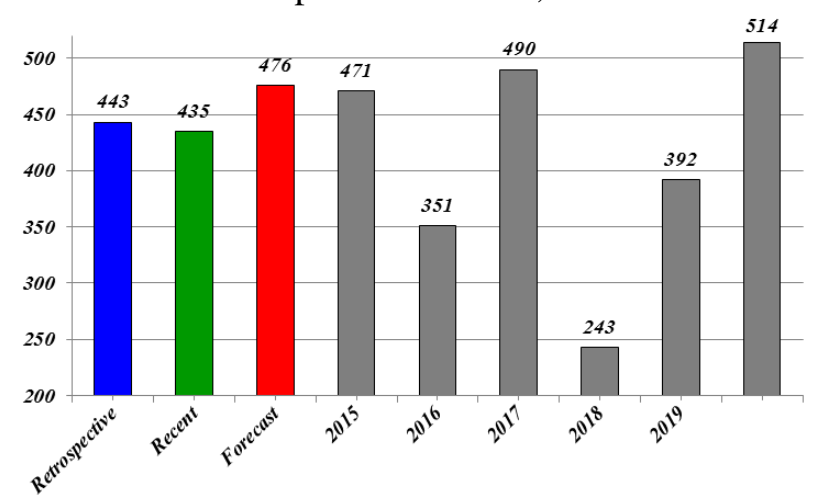

Relative air humidity, \%

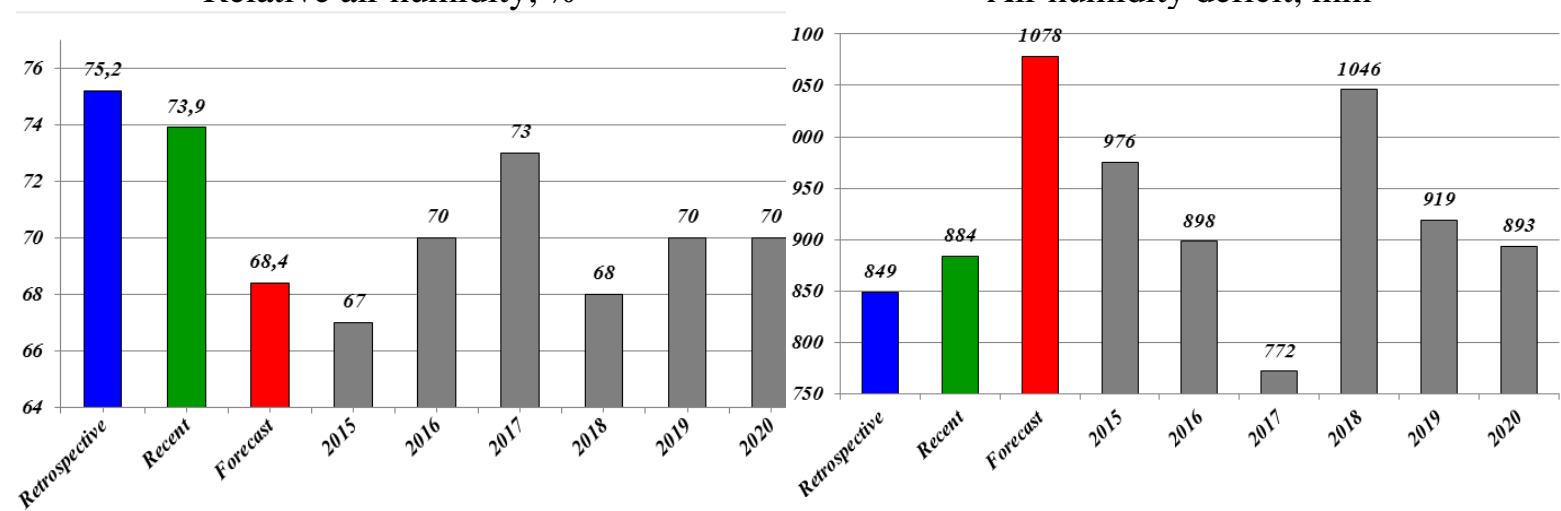

Fig. 1. Comparative assessment of average annual norms of vegetation values of the indicators of the main meteorological factors for conditions of Western Polesie by the considered levels and periods

According to many studies $[4 ; 5 ; 17]$, covering a wide range of regions, the negative impact of climate on crop yields will be more common than positive.

Attention should be paid to the expansion of the boundaries of agriculture in many countries, since it can not only be caused by global changes in the region (population growth, changes in the landscape and natural and climatic conditions), but also causes other changes.

Currently, the agricultural industry in Ukraine is not extremely vulnerable to climate change yet. However, changes in the weather conditions (an increase in air temperature, uneven distribution of precipitation, which are stormy in the warm season, ineffective accumulation of moisture in the soil, etc.) lead to an increase in the number and intensity of arid phenomena. Together with other negative factors of anthropogenic impact, this can lead to the expansion of the zone of risky agriculture and desertification in the southern regions of Ukraine. Due to intense warming over the past decades there have been changes in the structure of agricultural production, the area under agricultural crops and levels of the yield.

According to [19-22], the climate plays a decisive role in the formation of agroecological conditions for agricultural production. One of the most important tasks that must be solved when studying it is the need for knowledge: what kind of agricultural crops are profitable to grow in a particular area; how the climate affects the soil on which these crops are grown; what methods are best used when growing them.

Climate has played and still has a decisive role as one of the leading factors in soil formation, vegetation and productivity of agricultural crops. 
Solar energy absorbed by the soil is spent on processes such as heating, evaporation, transpiration, photosynthesis, humus synthesis, and so on. The sum of active temperatures is traditionally used for agronomic and soil assessment of the territorial thermal regime.

An increase in the average annual temperature, the value of the radiation balance and the sum of active temperatures per year lead to an increase in the intensity of weathering, the synthesis of organic matter, the activation of the vital activity of animals and microorganisms, an increase in the intensity of soil-forming processes, as well as to a reduction in the interphase periods and the vegetation cycle and, accordingly, the onset of earlier terms of ripening and harvesting of cultivated zoned agricultural crops.

One of the elementary processes of soil formation is evaporation of the soil moisture, which, first of all, depends on the temperature. An increase in precipitation as a result of increased leaching of nutrient (mineral and organic) substances from the soil will also negatively affect soil fertility. The regions with sufficient and excessive moisture can suffer the most from this, which occurs in the northwestern regions of Ukraine and can lead to a decrease in soil fertility in this territory by $20 \%$ or more.

Nowadays in Ukraine there are about 1 million hectares of peatlands drained as a result of reclamation, the bulk of which is located in the right-bank Polesie within the Kiev, Volyn, Rivne and Zhytomyr regions. Peat bogs, as one of the most vulnerable wetlands, are threatened with degradation on a global scale today.

In especially dry years in the spring and summer months, protracted fires in the peatlands of Polesie are continuing for several weeks, or even more than a month. In recent years, long-term fires have been recorded annually and have led to local environmental disasters.

Thus, it is expected that in the near future climate change in Ukraine will have both positive and negative impact on agriculture. Moreover, the balance of these influences will be different in different agroclimatic zones. A decrease in the duration of the growing season will be beneficial for agriculture in the northern half of the country, and it will lead to an increase in droughts for the southern half of the country.

Agro-climatic resources can increase and significantly improve the efficiency of agriculture. The implementation of this is possible in the case of the rise and radical adaptation of agriculture to climatic conditions synchronized with the pace of climate change, that is, it is necessary to optimize natural reclamation conditions with the help of specially developed reclamation measures. Otherwise, climate change can lead to a drop in the average yield and instability of agricultural production in general $[21 ; 23]$.

The focus of reclamation activities is determined, first of all, by the required level of productivity of the agricultural land used with a regulated water regime of soil, in accordance with the level of requirements of agricultural crops to the conditions of their cultivation. Therefore, it is of interest to assess changes in the weather and climatic conditions and their impact on the general natural reclamation regime and productivity of reclaimed lands at the regional level. That is, it is necessary to identify general tendencies and the nature of the relation in the system of weather and climatic conditions $\Rightarrow$ natural reclamation regime $\Rightarrow$ productivity of drained lands on the example of the zone of Western Polesie of Ukraine.

The generalized results of the predictive assessment of the impact of changes in weather and climatic conditions on the productivity of the main cultivated zoned agricultural crops on drained lands under the considered recent and forecast conditions in relation to retrospective ones for the most indicative dry $(p=70 \%)$ and very dry $(p=90 \%)$ vegetation periods obtained as a result of the obtained simulation modeling on ECM are presented in Table 1.

The presented data (Table 1) convincingly indicate that the existing recent and expected predicted climate changes, associated primarily with an increase in the temperature regime and a decrease in the moisture supply of the territories (Fig. 1), in general, worsen the conditions and can lead to a decrease in the yield of traditional zoned varieties and types of agricultural crops grown on drained lands on average from 15 to $60 \%$. It should be noted that this level of yield decline, and even lower, takes place in the last observed years with the manifestation of abnormal phenomena in comparison with the retrospective period (Fig. 1), when growing crops on drained lands without additional moisture in real production conditions. 
General trends towards decrease in productivity of the main cultivated zoned agricultural crops on drained lands in changeable climatic conditions

\begin{tabular}{|c|c|c|c|c|c|c|c|c|}
\hline \multirow[t]{3}{*}{ Agricultural crops } & \multicolumn{8}{|c|}{$\begin{array}{l}\text { Deviations of the main indicators from the normalized average annual } \\
\text { favorable conditions, } \%\end{array}$} \\
\hline & \multicolumn{4}{|c|}{ Recent conditions } & \multicolumn{4}{|c|}{ Forecast conditions } \\
\hline & $\Delta \tau_{T}$ & $\Delta Y_{T}$ & $\Delta Y_{W}$ & $\Delta Y$ & $\Delta \tau_{T}$ & $\Delta Y_{T}$ & $\Delta Y_{W}$ & $\Delta Y$ \\
\hline \multicolumn{9}{|c|}{ Dry growing season, $p=70 \%$} \\
\hline Winter cereals & 8.55 & 13.3 & 17.0 & 15.2 & 16.7 & 34.6 & 40.4 & 42.6 \\
\hline Potatoes & 7.70 & 22.2 & 22.0 & 29.3 & 15.4 & 45.2 & 43.9 & 46.8 \\
\hline Perennial grasses & 5.30 & 10.8 & 34.1 & 36.8 & 15.8 & 46.8 & 48.6 & 48.2 \\
\hline \multicolumn{9}{|c|}{ Very dry growing season, $p=90 \%$} \\
\hline Winter cereals & 25.0 & 37.4 & 38.8 & 38.5 & 33.3 & 48.2 & 43.3 & 43.6 \\
\hline Potatoes & 15.4 & 43.6 & 48.0 & 48.0 & 23.1 & 54.4 & 52.4 & 56.7 \\
\hline Perennial grasses & 26.3 & 38.8 & 43.8 & 43.8 & 31.6 & 60.8 & 59.2 & 62.4 \\
\hline
\end{tabular}

Note. Designations used in the table: $\Delta \tau_{T}$ - decrease in duration of the growing season of cultivated crops with an increase in temperature relative to its normalized average long-term one; $\Delta Y_{T}, \Delta Y_{W}$ - decrease in the yield of agricultural crops, when the temperature and water regimes deviate, respectively, from the normalized average long-term favorable conditions; $\Delta Y$ - general decrease in the yield of the main cultivated zoned crops on drained lands in changeable climatic conditions.

The projected increase in the air temperature and increased aridity under climate change, which are already observed today, will inevitably lead to a decrease in the natural moisture supply of the territory and an increase in potential evaporation and, accordingly, the total water demand, when growing crops on drained lands. In turn, the lack of natural moisture requires additional moistening of the grown crops through the implementation of appropriate water regulation technologies to moisten the drained lands.

Therefore, by analogy with the described above, a predictive assessment of changes in the water demand was made, when growing crops on the drained lands of Western Polesie of Ukraine in changeable climatic conditions to substantiate the appropriate adaptive solutions.

The main results of comparative assessment of the water demand according to the main indicators of the regime and technique of subsurface moistening (irrigation and moisture rates, the number of irrigations, etc.), as the most common technology for moistening drained lands, for the existing and forecast conditions under consideration are presented (Fig. 2) in the form of diagrams, which in a comparable form reflect the values of the maximum norms of water supply for the most indicative very dry $(p=90 \%)$ year in the ten-day section, when growing the main crops on peat soil.

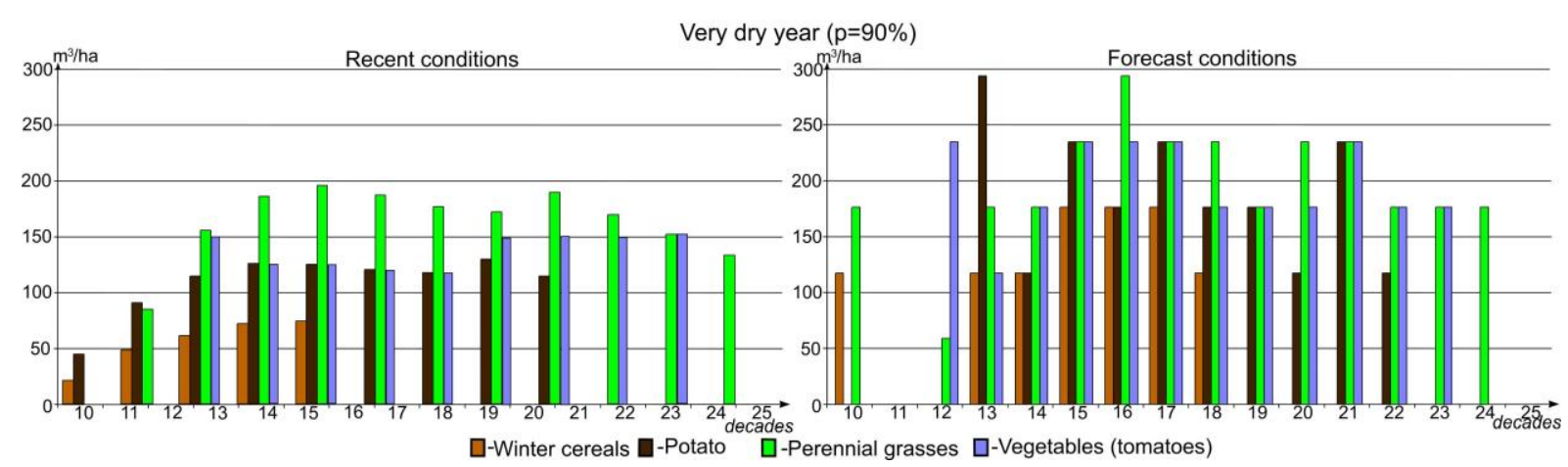

Fig. 2. Dynamics of the maximum average ten-day values of water demand of cultivated crops according to water supply rates during dry growing seasons: $(p=90 \%)$ with subsurface moistening of drained lands

The results obtained to determine the total evaporation, water demand and technological efficiency of humidification of drained lands in the changeable climatic and agromeliorative conditions of Western Polesie of Ukraine indicate a possible increase in the water demand of grown crops by 1.5-2.0 times. This determines the need to reassess the functionality and technical condition of the existing drainage systems based on the transition to humidification of drained lands on an ongoing basis. 
Thus, at the existing rates and levels of changes in the weather and climatic conditions, a deterioration in natural reclamation conditions in general, both in the Polesie zone and in Ukraine as a whole should be expected. This will inevitably affect the functioning of water management and amelioration facilities and complexes as a result of corresponding changes in the ecological and economic resource, which determines the need to develop an adaptive regime, technological and technical measures for the management of these facilities on the basis of relevant research, comprehensive scientific industry, state and interstate programs.

The modern concept of adaptation to climate change is presented in the Fifth Assessment Report of the IPCC and Working Group II and was further developed in the cycle of the Sixth Assessment Report (2015-2022) [12-14].

At the same time, it is stated that one of the most important components of playing a leading role in the adaptation process is a clear understanding of why they are carried out, and what adaptation measures can be introduced. As basic, various measures are considered to address different aspects of adaptation (Fig. 3.)

\begin{tabular}{|l|l|l|l|}
$\begin{array}{l}\text { Activities aimed at the } \\
\text { formation of adaptive } \\
\text { potential }\end{array}$ & $\begin{array}{c}\text { Activities aimed at } \\
\text { reducing risk and } \\
\text { sensitivity }\end{array}$ & $\begin{array}{l}\text { Activities aimed at increasing } \\
\text { capacity to cope with the } \\
\text { consequences of emergency } \\
\text { events }\end{array}$ & $\begin{array}{l}\text { Activities to benefit from } \\
\text { climate change }\end{array}$ \\
\hline $\begin{array}{l}\text { Promote national and } \\
\text { public awareness of the } \\
\text { climate change process, } \\
\text { its consequences and the } \\
\text { ability to respond to them }\end{array}$ & $\begin{array}{l}\text { Preparatory measures } \\
\text { aimed at increasing the } \\
\text { degree of resilience and } \\
\text { protection from short- } \\
\text { term, medium-term and }\end{array}$ & $\begin{array}{l}\text { Activities during and after } \\
\text { extreme events (floods, fires, } \\
\text { hurricanes) to reduce the } \\
\text { consequences and curb natural } \\
\text { changes }\end{array}$ & $\begin{array}{l}\text { Activities to benefit from } \\
\text { climate change; climate } \\
\text { change is beneficial for } \\
\text { someone }\end{array}$ \\
$\begin{array}{l}\text { Examples: the research } \\
\text { of the impact of climate } \\
\text { change, disaster response } \\
\text { plans, etc. }\end{array}$ & $\begin{array}{l}\text { Examples: early warning } \\
\text { systems, new varieties of } \\
\text { crops, etc. }\end{array}$ & $\begin{array}{l}\text { Examples: cooling areas during } \\
\text { extreme heat, a dedicated } \\
\text { emergency fund, special teams } \\
\text { on hand to clear roads, etc. }\end{array}$ & $\begin{array}{l}\text { Examples: benefit from } \\
\text { longer growing seasons of } \\
\text { new commercial crops }\end{array}$ \\
\hline
\end{tabular}

\section{Fig. 3. General characteristics of adaptation measures [14]}

Implementation of the measures to adapt agriculture to climate change must necessarily provide, first of all, in accordance with the generally accepted European practice, a set of activities to raise awareness of the public and land users.

The general methodology for carrying out such actions can be presented in the form of the following algorithm (Fig. 4.)

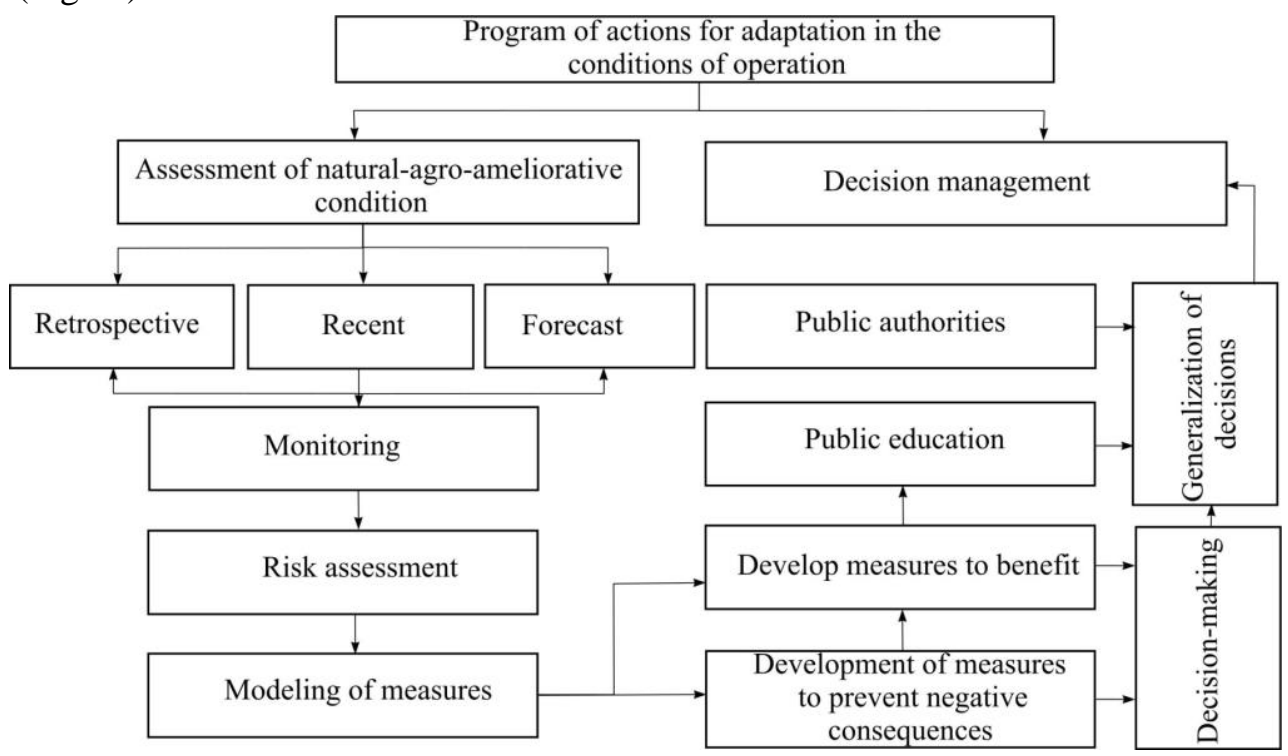

Fig. 4. Algorithm for making decisions on adaptation in an agroecosystem 
As for adaptive measures for reclaimed agricultural land, then, according to $[1 ; 2$; etc.], for their development it is necessary to carry out much larger, in comparison with the minimum necessary, comprehensive research. Among other important research on adaptation of agricultural production to climate change in general, this research, including the drainage reclamation zone, should primarily be aimed at developing new energy, water and resource-saving methods of integrated land reclamation, the latest technical means of irrigation, water regulation, application of fertilizers and chemical ameliorants, irrigation and fertilization regimes for agricultural crops in accordance with the projected changes.

Therefore, based on the analysis and generalization of the content of international and national program documents regarding the need and general recommendations for the development of adaptive measures related to climate change, research results and general assessment of domestic and foreign scientists and specialists, as well as the results of our relevant research to assess the current state of changes in weather and climatic conditions, including in the Polesie zone, and their impact on the efficiency of agriculture, moisture supply and soil fertility, a set of measures has been developed to adapt agricultural production on drained lands, which will make it possible to effectively resist recent challenges associated with ongoing and expected climate changes (Table 2).

Table 2

General recommendations on the types of measures for adaptation of agricultural production on drained land in changeable climatic conditions

\begin{tabular}{|c|c|c|c|c|}
\hline $\begin{array}{l}\text { Organizational } \\
\text { and economic }\end{array}$ & $\begin{array}{l}\text { Agrotechnical } \\
\text { activities }\end{array}$ & $\begin{array}{c}\text { Agro-ameliorative } \\
\text { activities }\end{array}$ & \multicolumn{2}{|c|}{ Hydraulic engineering activities } \\
\hline \multicolumn{3}{|c|}{ Operational } & Project & Construction \\
\hline $\begin{array}{l}\text { Creation of } \\
\text { organizational and } \\
\text { advisory centres } \\
\text { to raise awareness } \\
\text { of the public and } \\
\text { land users. }\end{array}$ & $\begin{array}{l}\text { Changes in varieties and } \\
\text { the introduction of } \\
\text { crops that are resistant } \\
\text { to biotic and abiotic } \\
\text { threats associated with } \\
\text { climate change } \\
\text { (primarily temperature } \\
\text { and water regimes); } \\
\text { growing hybrid crops; } \\
\text { use of crops of later } \\
\text { ripening. }\end{array}$ & \begin{tabular}{|l} 
Improvement of \\
technologies and tillage \\
tools of drained soil \\
aimed at improving their \\
water-physical properties \\
and storage capacity on \\
the basis of \\
improvement, first of all, \\
technologies and means \\
of deep continuous \\
loosening of soil, which \\
will make it possible to \\
effectively accumulate \\
moisture in the soil \\
profile and on the drained \\
massif as a whole [23].
\end{tabular} & $\begin{array}{l}\text { Improvement of technologies } \\
\text { and water regulation regimes on } \\
\text { drained lands, their transfer to } \\
\text { regular humidification, } \\
\text { regulation and water } \\
\text { accumulation within the } \\
\text { system; } \\
\text { improvement of types and } \\
\text { design of hydroameliorative } \\
\text { systems on drained lands; } \\
\text { improvement of methods of } \\
\text { design and calculation of } \\
\text { drainage systems based on the } \\
\text { use of optimization methods in } \\
\text { compliance with modern } \\
\text { economic and environmental } \\
\text { requirements, widespread use } \\
\text { of information and computer } \\
\text { technologies [21]. }\end{array}$ & $\begin{array}{l}\text { New } \\
\text { construction, } \\
\text { reconstruction } \\
\text { and } \\
\text { modernization of } \\
\text { existing drainage } \\
\text { systems to } \\
\text { effectively meet } \\
\text { modern } \\
\text { challenges } \\
\text { associated with } \\
\text { ongoing and } \\
\text { expected climate } \\
\text { change. }\end{array}$ \\
\hline
\end{tabular}

\section{Conclusions}

The results obtained clearly indicate that the existing current and expected forecast climate changes, primarily associated with an increase in the temperature regime and a decrease in the moisture supply of territories, generally worsen the conditions and can lead to a decrease in the yield of cultivated traditional zoned agricultural varieties and types of crops on drained lands by an average of 15 to $60 \%$. At the same time, it is possible to increase the water demand of cultivated crops by 1.5-2.0 times, which determines the need to re-evaluate the functionality and technical condition of existing drainage systems.

Thus, in order to effectively counter current challenges associated with ongoing and expected climate changes, a set of adaptive agromeliorative, agrotechnical and hydraulic engineering measures has been developed and proposed, aimed at a gradual transition to the cultivation of new varieties and types of crops, effective regulation of the water regime, regulation and accumulation of moisture in the soil profile and within the system, the transition from the traditional periodic to the implementation and provision of regular moistening of drained lands, improvement of water regulation technologies, types and designs of drainage systems and their technical elements, methods of their design and calculation, corresponding to modern economic and environmental requirements. 


\section{References}

[1] Romashchenko M., Gusev Yu., Shatkovskiy A., Saidak R., Yatsyuk M., Shevchenko A. and Matiash T. Impact of climate change on water resources and agricultural production. Reclamation and water resources management, (1), 2020, pp. 5-22. DOI: 10.31073/mivg202001-235 (In Ukrainian).

[2] About approval of the Concept for the implementation of state policy in the field of climate change until 2030: Order of the Cabinet of Ministers № 932-r of December 7, 2016 [online] [29.04.2020] Available at: https://www.kmu.gov.ua/ua/npas/249573705 (In Ukrainian).

[3] Kovalenko P., Rokochynskiy A., Jeznach J., Koptyuk R., Volk P., Prykhodko N., Tykhenko R. Evaluation of climate change in Ukrainian part of Polissia region and ways of adaptation to it. Journal of Water and Land Development. 41 (IV-VI), 2019, pp. 77-82. DOI: 10.2478/jwld-20190030

[4] Moore F., Lobell D. Adaptation potential of European agriculture in response to climate change. Nature Climate Change, 4, 2014, pp. 610-614.

[5] Ciscar J. C., Rising J., Kopp R. E., Feyen, L. Assessing future climate change impacts in the EU and the USA: Insights and lessons from two continental-scale projects. Environmental Research Letters, 14 (8), 2019, 084010. DOI: 10.1088/1748-9326/ab281e

[6] Kolokytha E., Malamataris D. Integrated Water Management Approach for Adaptation to Climate Change in Highly Water Stressed Basins. Water Resour Manage 34, 2020, pp. 1173-1197. DOI: 10.1007/s11269-020-02492-w

[7] Rokochinskiy A., Jeznach J., Volk P., Turcheniuk V., Frolenkova N., Koptiuk, R. Reclamation projects development improvement technology considering optimization of drained lands water regulation based on BIM. Scientific Review Engineering and Environmental Sciences, 28 Issue 3(85), 2019, pp. 432-443. DOI: 10.22630/PNIKS.2019.28.3.40

[8] Mazhaiskiy Yu.A., Rokochinskiy A.N., Volchek A.A., Meshik O.P., Eznakh E. Environmental management of Polesie. Ryazan: Meshcher. Branch of All-Russian Research Institute of Hydrotechnics and Melioration Named after A.N. Kostyakova, 2017, 902 p. (In Russian).

[9] Rokochinskiy A.M. The scientific and practical aspects of optimization of water regulation of drained lands on ecological and economic principles: monograph. Rivne, NUWEE, 2010, 351p. (In Ukrainian).

[10] Romashchenko M.I., Saydak R.V., Matyash T.V. Development of irrigation and drainage as the basis of sustainable agriculture in Ukraine in climate change/IX International scientific and technical conference «Modern problems of water management, environmental protection, architecture and construction», 22-27 July. 2019, pp. 243-250. (In Georgian).

[11] Global temperature. NASA report. [online] [30.04.2020] Available at: https://climate.nasa.gov/vital-signs/global-temperature/ (In Ukrainian).

[12] Climate Change and Land. An IPCC Special Report on climate change, desertification, land degradation, sustainable land management, food security, and greenhouse gas fluxes in terrestrial ecosystems (IPCC) [online] [29.04.2020] Available at: https://www.ipcc.ch/reports/ (In Ukrainian).

[13] United Nations framework convention on climate change/ United Nations 1992. FCCC/ INFORMAL/84 GE.05-62220 (E) 200705. [online] [30.04.2020] Available at: https://unfccc.int/resource/docs/convkp/ conveng.pdf

[14] United Nations Convention to Combat Desertification. [online] [30.04.2020] Available at: https://www.unccd.int/official-documents (In Ukrainian).

[15] United Nations framework convention on climate change. Kyoto Protocol, Kyoto, 1998 [online] [30.04.2020] Available at: https://unfccc.int/ resource/docs/convkp/kpeng.pdf

[16] Paris Agreement/ United Nations. New York. 2016. pp. 1-30 [online] [30.04.2020] Available at: https://treaties.un.org/doc/Treaties/2016/02/20160215\%2006-03\%20PM/Ch_XXVII-7-d.pdf

[17] Eric E. Massey, 2012. The experience of the European Union in adapting to climate change and its application in Ukraine. Office of the Coordinator for Economic and Environmental Affairs of the OSCE 40 p. (In Ukrainian).

[18] About approval of the Concept for the implementation of state policy in the field of climate change until 2030: Order of the Cabinet of Ministers № 932-r of December 7, 2016 [online] [29.04.2020] Available at: https://www.kmu.gov.ua/ua/npas/249573705 (In Ukrainian). 
[19] The assessment of the impact of climate change on the economy of Ukraine/Ed. Stepanenko S.M, Poloviy A.M. 2011. Odessa: Ecology. 605 p. (In Ukrainian).

[20] Cook J. et al. Consensus on consensus: a synthesis of consensus estimates on human-caused global warming // Environmental Research Letters. 2016. Vol. 11. 4. pp. 1-7. DOI: 10.1088/17489326/11/4/048002

[21] Rokochynskyi A., Volk P., Turcheniuk V., Tokar L., Volk L., Mazhayskiy Y., Chernikova O. Construction and agricultural drainage parameter optimization considering economic and environmental requirements. ENGINEERING FOR RURAL DEVELOPMENT Jelgava, 2020, pp. 36-47. DOI: 10.22616/ERDev.2020.19.TF010

[22] Irrigation and drainage strategy in Ukraine until 2030. Approved by the order of the Cabinet of Ministers of Ukraine dated 14.08.2019 p. № 688-r [online] [23.04.2020] Available at: https://zakon.rada.gov.ua/laws/show/688-2019-\%D1\%80 (In Ukrainian).

[23] Mazhayskiy Y., Rokochynskiy A., Lukianchuk O., Turcheniuk V., Volk P., Chernikova O. Deep loosening as an effective adaptive agromeliorative practice on drained mineral soil of European Polesie in variable climatic conditions. ENGINEERING FOR RURAL DEVELOPMENT Jelgava, 20.-22.05, 2020 pp. 28-35. DOI: 10.22616/ERDev2020.19.TF009 